\title{
Auditory-Visual Discrimination in Adults with Postlingual Hearing Impairment and Cochlear Implants
}

\author{
Fabiane da Silva Pereira ${ }^{1}$ \\ Programa de Pós-Graduação em Teoria e Pesquisa do Comportamento, Universidade \\ Federal do Pará, Belém, PA, Brasil \\ Suelen Nicole da Silva Lobato \\ Programa de Pós-Graduação em Neurociências e Comportamento, Universidade \\ Federal do Pará, Belém, PA, Brasil \\ Juliana Sequeira César de Oliveira \\ Universidade Federal do Pará, Belém, PA, Brazil \\ Cyntia Tzue Yamaguchi \\ José Claudio de Barros Cordeiro \\ Hospital Universitário Bettina Ferro de Souza, Universidade Federal do Pará, \\ Belém, PA, Brasil \\ Olavo de Faria Galvão \\ Programa de Pós-Graduação em Neurociências e Comportamento, Universidade \\ Federal do Pará, Belém, PA, Brasil
}

\begin{abstract}
Aiming the evaluation of listener-behavior training on speaker-behavior, specifically if individuals with hearing impairment and cochlear implant would: (a) learn audio-visual conditional discriminations with conventional and non-conventional words; (b) form stimulus classes; (c) present generalized responses to other audio frequencies; and (d) transfer the acquired hearing competences to speaker repertoires, two adults with post-lingual hearing loss and cochlear implant were exposed to a seven phases' matching to sample conditional discriminations teaching program consisting of: 1) Pre-training of auditory-visual tasks using fading out; 2) Pre-test of naming to evaluate the speaker behavior, 3) Teaching relations between dictated words and figures; 4) Teaching relations between dictated and written words, 5) Test of class formation; 6) Test of hearing generalization; 7) Post-test of naming. The participants learned the directly taught relations, demonstrated class formation and generalization. Comparing pre- and post-tests, they showed higher correspondence between their speaker behavior and verbal community's speaker behavior. The possibilities of this methodology for speaking rehabilitation in this population is discussed.
\end{abstract}

Keywords: Auditory-visual discrimination, stimulus equivalence, cochlear implant.

Mailing address: Conjunto Providência, Quadra 22, Rua 7, n 411, Val-de-Cans, Belém, PA, Brazil 66110-101. Phones: 91 8110-1489/3257-9505. E-mail: fabpsi@gmail.com

Os dados relatados neste artigo foram extraídos da pesquisa de mestrado "Discriminação auditivo-visual em adultos com deficiência auditiva pós-lingual e implante coclear" da primeira autora sob orientação do quinto autor. Financiamentos: Bolsa de Mestrado Coordenação de Aperfeiçoamento de Pessoal de Nível Superior (CAPES) à primeira autora; Bolsa de Produtividade em Pesquisa P313514/2014-3 ao quinto autor; Instituto Nacional de Ciência e Tecnologia Sobre Comportamento, Cognição e Ensino. Conselho Nacional de Desenvolvimento Científico e Tecnológico - CNPQ (Processo \#573972/2008-7) e Fundação de Amparo à Pesquisa do Estado de São Paulo - FAPESP (Processo \#2008/57705-8). 


\section{Discriminação Auditivo-Visual em Adultos com Deficiência Auditiva Pós-Lingual e Implante Coclear}

\section{Resumo}

Com o objetivo de verificar o efeito do treino do comportamento de ouvinte sobre o de falante, e especificamente verificar se deficientes auditivos pós-linguais usuários de implante coclear: (a) aprenderiam discriminações condicionais auditivo-visuais com estímulos convencionais e não convencionais; (b) formariam classes dos estímulos correlacionados; (c) apresentariam desempenho generalizado para outras frequências auditivas; e (d) se estes repertórios afetariam o comportamento de falante, dois adultos com deficiência auditiva pós-lingual usuários de implante coclear foram expostos a um programa de ensino com questões de escolha de acordo com o modelo, em sete fases: 1) Prétreino de tarefas auditivo-visuais com utilização do fading out; 2) Pré-teste de nomeação para avaliar o comportamento de falante; 3) Ensino das relações entre palavras ditadas e figuras; 4) Ensino das relações entre palavras ditadas e escritas; 5) Teste de formação de classes; 6) Teste de generalização auditiva e 7) Pós-teste de nomeação. Os participantes aprenderam as relações ensinadas, formaram classes dos estímulos correlacionados e generalizaram o desempenho para uma voz de timbre diferente. Comparandose os pré e pós-testes, observou-se aumento no índice de correspondência do comportamento de falante com a comunidade verbal. Discutem-se as possibilidades dessa metodologia para a reabilitação da fala nessa população.

Palavras-chave: Discriminação auditiva-visual, equivalência de estímulos, implante coclear.

\section{Discriminación Visual-Auditiva en Adultos con Discapacidad Auditiva Postlocutiva y Implante Coclear}

\section{Resumen}

Con el objetivo de averiguar el efecto del entrenamiento de la conducta de oyente sobre la de hablante, verificar específicamente si discapacitados auditivos post-locutivos usuarios de IC: (a) aprenderían la discriminación condicional auditivo-visual de estímulos convencionales y no convencionales; (b) formarían clases de estímulos; (c) generalizarían a otra frecuencia; (d) si estos repertorios influyen en el comportamiento del orador, dos adultos con discapacidad auditiva post-lingual y usuarios de implante coclear fueron expuestos a un programa de enseñanza con cuestiones de selección por igualación a la muestra, en siete fases: 1) Pre-entrenamiento de tareas visual-auditivas con utilización del desvanecimiento (fading out); 2) Prueba previa de nombramiento para evaluar la conducta de hablante; 3 ) Entrenamiento de relaciones entre palabras dictadas y figuras; 4) Entrenamiento de relaciones entre palabras dictadas y escritas; 5) Prueba de formación de clases; 6) Prueba de generalización auditiva y 7) Prueba posterior de nombramiento. Los participantes aprendieron las relaciones enseñadas, demostraron formación de clases y generalización. La comparación de los pre y post tests mostró que, ellos presentaran índices de correspondencia más grandes con la comunidad verbal en el comportamiento de hablar. Se discute la importancia de esta metodología para la rehabilitación en esta población.

Palabras clave: Discriminación visual-auditiva, equivalencia de estímulos, implante coclear.

The paradigm of stimulus equivalence has been used as a behavioral technology for auditory rehabilitation of individuals with pre and postlingual deafness whose hearing sensitivity has been restored by a cochlear implant $(\mathrm{CI})$, regardless of the time of deprivation.

The CI is an electronic device with terminals that are surgically inserted into the inner ear 
(and, more specifically, into the organ of Corti). It turns sound energy into electrical pulses conducted by the auditory nerve with which the neural processing of hearing begins. It is indicated for patients with profound to severe bilateral sensorineural hearing loss and in cases of both pre and postlingual deafness (Bevilacqua, 1998; Clark, 1996).

In a simplified model of listener and speaker behavior that involves teaching of conditional relations between auditory stimuli and pictures or printed words, the stimulus equivalence paradigm has been used in the study of CI users to establish links between seeing, hearing, and speaking. The procedure includes testing the emergence of relations that were not directly taught between these visual stimuli and their oral naming.

The use of the stimulus equivalence paradigm for the investigation of CI functionality is still new. Studies on children with pre and postlingual hearing impairment have used the notion of a behavioral curriculum to establish listener repertoires, working from the simplest to the most complex tasks either through direct stimulation of the cochlea (da Silva et al., 2006), with conventional and unconventional linguistic stimuli, pseudo words (Almeida-Verdu et al., 2008), or the advancement of more complex repertoires, such as teaching students how to read sentences (Golfeto \& de Souza, 2015).

Neves (2014) reviewed the research that evaluated effects of this teaching procedure on listener and speaker behaviors among people with CIs and found that most studies had been conducted on children with prelingual hearing impairment. Later, Neves, Verdu, MortariMoret, and Silva (2015) examined the state-of-the-art research involving language and CIs and found an increase in publications on the subject, particularly evaluating and identifying possible factors that interfere with language processes in CI users. Of all the analyzed publications, however, only two of the 86 studies were conducted on adult postlingual CI users. This study, therefore, seeks to reduce the shortage of research on the adult $\mathrm{CI}$ user population, using the stimulus equivalence model as a methodological resource. This is a cutting-edge study in the geographical region where the participants are originally from, where, at the time of study, most people undergoing CI surgery were adults with postlingual hearing impairment.

Initial data have shown variations in performance among children, especially in those with a longer period of hearing loss and shorter time after implantation than others. In the discussion, the authors associate lower-than-expected performance with a lack of orofacial cues for the tasks presented on the computer (Almeida-Verdu et al., 2009, Souza, Almeida-Verdu, \& Bevilacqua, 2013).

More recent studies have investigated the exclusion procedure as a way of putting visual and auditory stimuli into the same class, thus facilitating the emergence of image naming and word reading (Anastácio-Pessan, Almeida-Verdu, Bevilacqua, \& Souza, 2015; Golfeto \& de Souza, 2015).

The "teaching by exclusion" procedure involves the use of a behavioral characteristic present among young children: when faced with a problem of choice between two options for comparison, people tend to choose a new option to solve a problem that is presented as a new problem when the other option was apt for solving another problem. The use of this procedure has been promising, with fewer tasks being required for learning the associations between spoken words, written words, and pictures (McIlvane, Munson, \& Stoddard, 1988).

The results of this research have shown that, in general, the learning of auditory-visual discrimination is gradual and that the listener's behavior is more quickly presented compared to the speaker's behavior. All studies have demonstrated class formation, with conventional words and pseudo words after successive testing (Anastácio-Pessan et al., 2015), as well as the learning of sentence reading and intelligible speech (Golfeto \& de Souza, 2015).

During the period of deafness, postlingual implant users learned to use alternative means of hearing to understand and interact, such as 
lip reading, which makes it difficult for auditory stimuli to acquire function. The context, facial expressions, and lip movements of the interlocutors facilitate understanding when auditory stimuli are insufficient. For implant users in this situation, the teaching of correlations between spoken words and pseudo words and corresponding images in controlled conditions using the stimulus equivalence paradigm have been adopted as ways to ensure that the answer is based only on auditory stimuli, thus preventing the aforementioned means of assistance from interfering. The use of pseudo words establishes a control condition to investigate the learning of relationships in which additional tips are not available, even for people with postlingual deafness with an established oral code.

Given the relevance of adapting the paradigm to provide implant users with this technology to support the construction of a repertoire of oral linguistic communication, the objectives of this study were to evaluate the procedure variables involved in training in auditoryvisual discrimination with conditional relations between spoken words and pseudo words, images, and written words, and to determine whether training would facilitate the emergence of full-match vocalizations, generalized to voices of other pitches in CI users with postlingual hearing impairment. In summary, the objective was to determine whether CI users with postlingual hearing impairment would: (a) learn conditional auditory-visual discriminations with conventional and unconventional stimuli; (b) form stimulus classes; (c) generalize to other auditory frequencies; and (d) experience effects on their behavior as a result of these repertoires.

\section{Method}

\section{Participants}

The study included a man and a woman, referred to as Claudio and Ana (not their real names), with profound bilateral postlingual sensorineural hearing loss and who are also CI users. Both were 45 years old and their highest level of education was till the eighth grade. At the beginning of the study, Claudio had experienced five months of hearing loss and had used CI for four months (Nucleus 24 model). He had experienced a year and two months of hearing loss by the end of the study. Ana had experienced nine years of hearing loss and had used CI for eight months (Med-El model) at the beginning of the study, and one year and three months by the end of the study.

\section{Ethical Considerations}

The participants signed an informed consent form approved by the Research Ethics Committee for Human Subjects of the Institute of Health Sciences of Federal University of Pará (CAEE Registry No. 0268.0.073.000-12 and Opinion No. 039/12).

\section{Instruments}

The study involved a computer with touch screen and the EAM software, version 4.0.04, developed by Dráuzio Capobianco and modified by Carlos Picanço (Souza, 2010).

A reference monitor used in professional studios was used as the audio system. It offers high fidelity in sound reproduction with a cabinet size of $15.0 \times 10.0 \times 8.5 \mathrm{~cm}$ with magnetic shielding. Frequency response was $45 \mathrm{kHz}$ to 18 $\mathrm{kHz}$, with a sensitivity of $88 \mathrm{~dB}$ and a crossover frequency of $2.5 \mathrm{kHz}$.

Auditive and visual stimuli were used. Recordings of adult female and male voices were used as auditive stimuli and images and written words were used as visual stimuli. The visual stimuli were presented in square "windows" of approximately five centimeters in length and were in one of the nine possible positions of a $3 \times 3$ matrix on the screen of the monitor. Both conventional and unconventional stimuli were presented with pseudo words formed using possible phonological combinations in our verbal community but without meaning in the language. Mono-, di-, tri-, and polysyllabic words and corresponding images were used. Unconventional dissyllabic words were taken from the study by Anastácio-Pessan et al. (2015) and images were obtained from the Internet (unconventional stimuli). The images used in training can be seen in Figure 1. 


\begin{tabular}{|c|c|c|c|c|c|c|c|}
\hline \multicolumn{4}{|c|}{ Baseline stimuli } & \multicolumn{4}{|c|}{ Unconventional stimuli } \\
\hline Auditory & Image & & Written Word & Auditory & Image & & Written Word \\
\hline /Mão/ (A1) & & (B1) & MÃO (C1) 'hand' & /Pafe/(A5) & & (B5) & PAFE (C5) \\
\hline /kaho/(A2) & & ( (B2) & CARRO (C2) 'car' & /Duka/ (A6) & & (B6) & DUCA (C6) \\
\hline /kavalo/ (A3) & & (В3) & $\begin{array}{l}\text { CAVALO (C3) } \\
\text { 'horse' }\end{array}$ & /Tiba/ (A7) & & (B7) & TIBA (C7) \\
\hline /abakafi/ (A4) & & (B4) & $\begin{array}{l}\text { ABACAXI (C4) } \\
\text { 'pineapple' }\end{array}$ & /Zigo/ (A8) & & (B8) & $\mathrm{ZIGO}(\mathrm{C} 8)$ \\
\hline
\end{tabular}

Figure 1. Stimuli used in Phases 3 and 6 of this study.

\section{Data Collection Procedure}

The teaching program sought to strengthen the hearing abilities of the participants by exposing them to tasks in which they are required to focus on the auditory stimuli and choose the corresponding image or written word. Next, they were exposed to the test of correlations derived from the stimuli taught; the speakers' skills in naming objects and reading tasks were also tested.

The experimental environment consisted of an artificially lit and air-conditioned room with a touch screen computer, mouse, sound system, and a chair. The participant sat in front of the monitor on which the stimuli that should be paired to the sample were presented. They began with the presentation of either a visual or an audiovisual stimulus; when the stimulus was touched, it disappeared and four comparison stimuli were presented, one of which, once defined as correct and touched, displayed the phrase "you got it right" on the screen immediately after the participant's response for three seconds before a new trial became available. When incorrect answers were selected, a black screen appeared following the response for three seconds and a new trial was presented. Seven phases ranging from training to tests were performed. Correction for incorrect answers was made available only during the training trials. The phases of the procedure are summarized in Table 1 and described below.

Phase 1. Participants were exposed to a pretest, in which they received instructions to name pictures and read words in order to assess their vocalizations and select the prearranged stimuli that would make up the following phases. There were no programmed results for the answers during this phase. A total of 32 images and 32 words corresponding to the names of those images were used. The images were chosen based on their names and the number of syllables in the words (mono-, di-, tri-, or polysyllabic). There were eight stimuli for each syllable category. Based on the performance of the participants, four conventional stimuli, vocalized with a full match, were selected during the image naming test.

Phase 2. Aiming to establish control by auditory stimulation, audiovisual training was provided with a pre-composed sample presentation. It included simultaneous sounds 
Table 1

Sequence of Teaching-Phase Tasks Employed in this Study, the Target Repertoires of Each Phase, Stimuli, and the Criterion Used to Determine a Passing Score

\begin{tabular}{ccccc}
\hline Phase & Task & Target Repertoire & Stimulus & Criterion \\
\hline 1 & Pre-Test & $\begin{array}{c}\text { Assessment: Reading } \\
\text { and Image Naming }\end{array}$ & Conventional & - \\
2 & Pre-Training & AVMTS* & Conventional & $90 \%$ \\
3 & AB Teaching & AVMTS & Conventional and Unconventional & $90 \%$ \\
4 & AC Teaching & AVMTS & Conventional and Unconventional & $90 \%$ \\
5 & Class Formation Test & CB/BC & Unconventional & - \\
6 & Generalization Test & AVMTS & Unconventional & - \\
7 & Post-Test & & Conventional & - \\
\hline
\end{tabular}

Note. Identity Matching to Sample (IDMTS). *AVMTS - Auditory-visual Matching-to-sample.

and images that faded out. The image became increasingly transparent in three stages $(25 \%$, $50 \%$, and $75 \%$ ) until only a yellow square remained, regardless of what the sound was. To carry out pre-training, four stimuli with twosyllable names in Portuguese were used: bola "ball," fogo "fire," sino "bell," and casa "house," the same as those used by Anastácio-Pessan et al. (2015). These stimuli were not presented again in other phases of the study. Only correct choices were reinforced.

In Phases 3 and 4, presented below, the auditory-visual discrimination (AVMTS) procedure of teaching by exclusion was used. Conventional stimuli selected in the pre-test (baseline) as well as unconventional stimuli were used.

Phase 3. In this phase, the training on correlations between spoken words (Set A) and images (Set B) was started via the exclusion procedure (Dixon, 1977; McIlvane \& Stoddard, 1981). Four unconventional stimuli were inserted (see Figure 1). The training was carried out as a sequence of four blocks of trials in which the correlations taught varied as follows:

- Block 1 - Baseline: conditional auditoryvisual discrimination with conventional stimuli selected in the pre-test (baseline)

- Block 2 - Learning verified by exclusion: conditional auditory-visual discrimination with unconventional stimuli. Trials were composed of an unconventional sound func- tioning as a sample stimulus, such as /pafe/, and four images as comparison stimuli, three of which were baseline and one was an unconventional image corresponding to the sample. In this condition, the participant was able to select the unconventional image by excluding known images or to establish a direct correlation between the unconventional image and the sound. Neither correct nor incorrect responses received reinforcement.

- Block 3 - Control for novelty: the sound presented as a sample stimulus was always taken from the baseline, and the images presented for stimulus comparison included three unconventional images and one baseline image. In this situation, the participant had to choose the image corresponding to the sound, rejecting the unconventional images. The choice of a baseline correlation indicated a continuation of this correlation and ruled out any controls for novelty that could have been established in the Block 2 trials.

- Block 4 - Learning: in this block, only unconventional correlations were presented: both the sound presented as a sample stimulus and the images presented as comparison stimuli were unconventional.

- The trial blocks were presented in succession with 12 trials per block, regardless of 
the number of correct answers. If the participant received $100 \%$ scores in Blocks 1 , 2 , and 3 and did not achieve this score in Block 4, which was expected in the initial sessions, the following sessions would be composed of 24 trials of only unconventional correlations, with six trials for each undefined correlation. The criterion for learning was achieving $90 \%$ accuracy in all trial blocks.

Phase 4. Training correlations between spoken words (Set A) and written words (Set C). The procedure applied in Phase 4 had the same characteristics as Phase 3, except that Set B stimuli (images) were replaced with Set $\mathrm{C}$ stimuli (written words). The criterion for a passing score in this phase was also to achieve $90 \%$ accuracy in all trial blocks.

Phase 5. Test of transitive and symmetrical correlations. After reaching the learning criterion, participants were exposed to class formation tests $\mathrm{CB} / \mathrm{BC}$ in which the relations $\mathrm{CB}$, between written words (Set $C$ ) as sample and images (Set B) as comparisons were evaluated, and relations $\mathrm{BC}$, comprising images (Set B) as sample and written words (Set C) as comparison stimuli were also evaluated. Forty trials were presented: 24 test trials and 16 baseline trials in four blocks.

Phase 6. Generalization Test. Participants were exposed to a new auditory generalization test, with characteristics similar to those of Phase 5, intended to determine whether the correlation remained when the words presented were recorded with a different timbre (a male voice). The objective of this test was to determine whether, after providing a correct answer on correlations between unconventional images and sounds, participants could still respond accurately to sounds of different frequencies from those presented during training. This phase included 32 trials: 8 baseline trials and 24 test trials. The participant was exposed to the next phase, regardless of the number of correct answers.

Phase 7. Post-Test. As in the pre-test (Phase 1), the participants named images and read words to evaluate the effect of training on their vocalization.

\section{Data Analysis Procedures}

Vocalization Evaluations. Vocalizations were assessed by two observers (the researcher and an independent observer) and the discrepancies were reassessed until an agreement rate of $90 \%$ was achieved (Delgado \& Bevilacqua, 1999; Kazdin, 1982).

The participants' vocalizations were assessed based on Anastácio-Pessan et al. (2015), in four categories (full match, partial match, vocalization with no match, and omissions), defined as follows: (a) Full match: vocalizations issued with point-to-point matching with the conventional use. (b) Partial match: words uttered with phonemic changes or cases in which the participant uttered all of the phonemes but changed the nasalization or tone of some of the phonemes. (c) No match: vocalizations of another word that did not have any phoneme in common with the conventional word. Example: when faced with an image of the moon, the participant uttered "sun." (d) Omission: when the participant did not utter any sounds after the presentation of the image or written word.

Criterion for a Passing Score for the Phase. A criterion of achieving $90 \%$ correct answers in one session were established so that participants could move from one teaching phase to another. No criteria were established for the test phases.

\section{Results}

The results are organized by phases. The results of Phases 1 and 7, the pre- and post-tests, can be seen in Figure 2, displayed according to the number of syllables of the words.

In the pre-test, Ana (who had experienced a longer duration of hearing loss) exhibited more omissions in the image-naming task with a higher score for images with disyllable names and a less accurate score for images with monosyllabic names. Ana's omissions in the pre-test occurred when she was presented with the images of a turtle, a swing, a cross, and a train. 


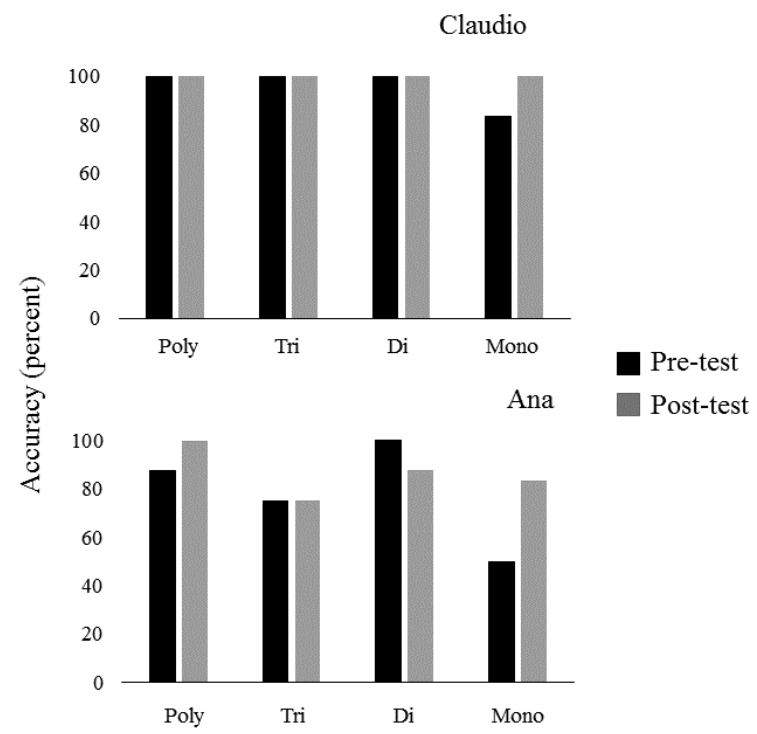

Figure 2. Percentage of correct answers from the participants in the image-naming task in the PreTest (Phase 1) and the Post-Test (Phase 7), organized by number of syllables in the words.

In the post-test, Ana exhibited two omissions in the naming task when presented with the images of a swing and a wastebasket, and she presented one unmatched vocalization when presented with the flower image, for which she uttered /sol/ "sun."

Ana's vocalizations had an increase in verbal correspondence when she was presented with images with polysyllabic and monosyllabic names; specifically, she had a greater number of vocalizations with a full match when presented with images with polysyllabic names and had more errors in images with monosyllabic names. In the reading task and on the pre-test, her performance was categorized as a full match for words in all syllable categories.

In the pre-test (Phase 1), Claudio's vocalizations were evaluated as full matches for all images, except for one omission when presented with an image with a monosyllabic name. In the post-test (Phase 7), all of Claudio's vocalizations were full matches. In the reading task, his performance remained identical to that of the pre-test.

In Phase 2 (pre-training), both participants outperformed the established criteria, presenting the prerequisite repertoires for the following phases in a single session.

In Phases 3 and 4, both participants learned the audiovisual relations between spoken words and images with unconventional stimuli. In Phase 3, Ana and Claudio required 13 and 14 exposures, respectively, to the block of relations between sounds and unconventional images to meet the criteria, as can be seen in Figure 3.

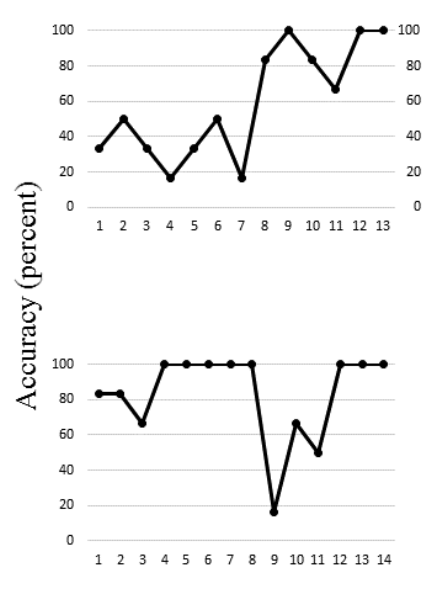

PAFE
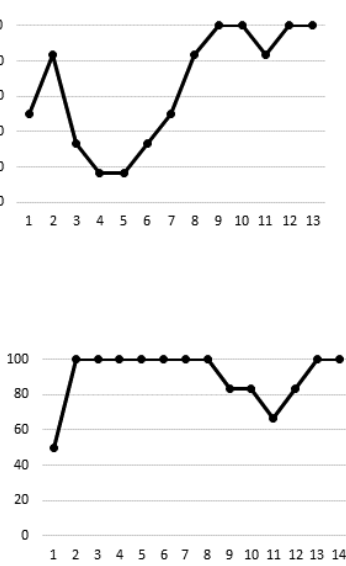

DUCA
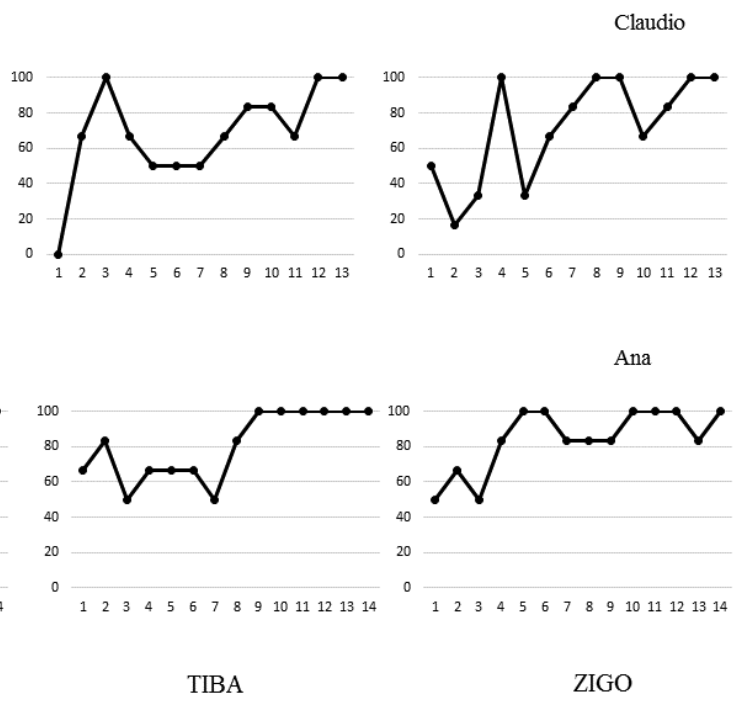

Figure 3. Participant performance indicating undefined relations between the auditory sample and unconventional images in Phase 3. 
The participants' scores in Phase 3 were accurate in the relations among unconventional stimuli (via exclusion). They remained stable in their baseline responses, meaning that they did not respond under the effect of novelty, rather they consistently responded to the association established at the baseline. The possible effect of a control by novelty with the exposure to Block 2 with unconventional stimuli can therefore be discarded; however, Block 4 (learning) required more exposures to reach the criterion.

In Phase 4 (the training of relations between spoken words and written words), participants achieved $100 \%$ scores after a single exposure to the training.

On the class formation test in Phase 5, the participants provided evidence of class expansion with the emergence of relations that were not directly taught. Claudio achieved 91.6\% accuracy on the test trials for relation between images as sample stimuli and written words as comparison stimuli (BC) and $100 \%$ accuracy on test trials to relate written words to images (CB), while Ana achieved $100 \%$ on all trial types.

On the generalization test, both participants achieved overall scores of $100 \%$ accuracy in a single session. Participants reported that they did not perceive the auditory stimuli presented as a male voice, although they noted it was a different voice from the voice used during training.

\section{Discussion}

The objectives to investigate whether adult CI users with different durations of hearing loss (a) would present accurate performance on conditional auditory-visual discriminations with conventional and unconventional stimuli, (b) would form stimulus classes consistent with the learned relations, (c) would generalize the function of auditory stimuli to another frequency, (d) would have their repertoires affected by the speaker's behavior, have all been achieved.

The data obtained are consistent with the literature, demonstrating the efficacy of the audiovisual pairing model, fading, and exclusion for teaching new repertoires to people with lim- ited verbal repertoires (Bagaiolo \& Micheletto, 2004).

Although the participants had five months (Claudio) and nine years (Ana) of hearing loss, both presented speaker behavior with high levels of consistency with the verbal community in the voicing tasks, albeit with some delay relative to the normal speech standard. The data obtained on the vocalization tests corroborate Battaglini et al. (2013) and Golfeto and de Souza (2015) regarding the issue of vocalizations with higher matches in the word reading task than in the image-naming task. Battaglini et al. (2013) argue that word reading is made easier when there is a graphic correspondence in the letter sequence of the spoken word to the sounds; in other words, the visual control specifies each of the vocalizations to be issued.

The participants learned the relation between auditory stimuli and images in the training phase, forming classes of auditory stimuli, images, and corresponding written words. From the perspective of CI usefulness, this result confirms previous studies (Anastácio-Pessan et al., 2015; Golfeto \& de Souza, 2015), which have shown that CI restores sensitivity to sound, but auditory-visual discrimination and the ability to consistently respond to sounds associated with images and written words need to be taught (in the case of prelingual patients) and re-taught to patients with postlingual hearing loss to achieve the competence of a speaker-listener able to communicate, read, and talk to other people while being in control of the relations between sounds and other events.

Our data agree with those presented in the literature, showing that CI users with both prelingual and postlingual hearing impartment show gains in communication with the verbal community after ostensible training of the listener repertoire (Almeida-Verdu et al., 2008; Anastácio-Pessan et al., 2015; Golfeto \& de Souza, 2015).

By linking the duration of hearing loss with auditory discrimination performance, the data obtained in this study also agree with the data presented in the literature: the longer the dura- 
tion of hearing deprivation, the greater the difficulty in hearing rehabilitation. This is observed, for example, in the differences in participants' abilities to reach the criterion in the study by Anastácio-Pessan et al. (2015). In most cases, these patients required one exposure block, while the participants in this study required 13 and 14 exposures. However, data on a higher number of postlingual implant users are needed to establish the correlation.

While studies on the acquisition and operation of symbolic behavior in the literature generally involve patients with prelingual hearing loss, especially children; this study's participants were adults with postlingual hearing impairment, a different population, but one that is also in need of care. And even in this population, which is assumed to have developed linguistic performance, it is argued that the verbal operants involved in speaker and listener abilities after CI implantation, seem to require specific learning conditions (Almeida-Verdu et al., 2008; Wei, Cao, Jin, Chen, \& Zeng, 2007).

Given the satisfactory results, it seems to be relevant to show that people with postlingual hearing loss with CIs after different durations of hearing loss, once exposed to an auditory and speaking skill education program focused on long and short word discrimination, can learn new symbolic relations between auditory and visual stimuli.

The positive results on the generalization tests involving a different auditory frequency indicate that CIs are able to provide users with sufficient hearing sensitivity to discriminate words in the different voice timbres used in teaching. This repertoire is functional in the daily life of human beings, in traffic, at work, at home, etc., because in daily life, different sounds should be recognized as functionally identical, such as the sounds of horns, phones, etc. A message must be recognized at different frequencies, and a person who is hearing is expected to be able to answer someone at the door, hear a knock on the door, clapping, or a ringing doorbell, for example. However, the reports from the participants evidenced poor discrimination between male and female voices.
This finding points to the need for new studies to assess and train for more accurate discrimination between timbres and intonations.

The authors also encourage future studies using environmental noise as a discriminative stimulus to approximate the experimental environment of the reality of the participants and the presentation of onomatopoeic stimuli, which may facilitate the first steps for the rehabilitation of this population with recent hearing.

One difficulty of studies on patients with CIs performed from the perspective of the stimulus equivalence paradigm is their long duration with many stages and trials per phase (Almeida-Verdu et al., 2008; Anastácio-Pessan et al., 2015; Golfeto \& de Souza, 2015). Given this difficulty, this study sought to adopt a procedure with few phases and trials in each phase, in an attempt to prevent fatigue and possible withdrawal from the study.

A limitation of this and other studies involving CI users is the procedure used, which inserts a sequence of training contingencies to teach listening skills and tests the effect of listener training on the speaker only after training. This procedure conflicts with the development of language in a natural environment in which children with typical development learn alternating speaker and listener behaviors, when in contact with adults. Presenting a vocal stimulus such as the name of an object, for example, in the presence of both the object and the child, may be a favorable condition for the child to learn, via social reinforcement, how to develop a conventional behavior in relation to the object. Horne and Lowe (1996) argue that the echoic would be an important link in the establishment of listener and speaker behavior. Thus, when faced with an auditory stimulus, the child responds by echoing and the caregiver reinforces this performance (Skinner, 1957). However, after the child has already acquired listener behavior, auditory stimuli beyond the echoic will also reinforce the child's listening behavior. At this point, the child becomes a speaker-listener in relation to his or her own verbal stimulus. Another element pertaining to the development of speaker behavior is the verbal-tactile operant in which a response 
(naming, for example) is evoked by a particular event (Horne \& Lowe, 1996).

In the establishment of verbal skills, the most likely form of touch is through previously established echoic and listener behavior (Horne \& Lowe, 1996).

Future studies may present procedures in which listener and speaker skills are presented in an alternating fashion within a single session. Multiple exemplar instruction (MEI) has been found to be promising to develop verbal speaker and listener repertoires in children with atypical development (Greer \& Ross, 2008).

This study sought to collaborate in generating behavioral technology that is applicable in therapeutic and educational environments, favoring auditory rehabilitation by a teaching program with demonstrated efficacy in the literature. Additionally, it has contributed to the knowledge of conditions in which CI users with postlingual hearing loss can acquire symbolic competence by planning of effective teaching procedures to expand their verbal repertoires.

\section{References}

Almeida-Verdu, A. C. M., de Souza, D. G., Bevilacqua, M. C., \& Souza, F. C. (2009). Imitação vocal e nomeação de figuras em deficientes auditivos usuários de implante coclear: Estudo exploratório [Vocal imitation and picture naming in users of cochlear implant: An exploratory study]. Revista Brasileira de Análise do Comportamento/Brazilian Journal of Behavior Analysis, 5, 63-78.

Almeida-Verdu, A. C., Huziwara, E. M., de Souza, D. G., de Rose, J. C., Bevilacqua, M. C., Lopes, J., \& McIlvane, W. J. (2008). Relational learning in children with deafness and cochlear implants. Journal of the Experimental Analysis of Behavior, 89, 407-424. doi:10.1901/jeab.2008-89-407

Anastácio-Pessan, F. L., Almeida-Verdu, A. C. M., Bevilacqua, M. C., \& Souza, D. G. (2015). Usando o paradigma de equivalência para aumentar a correspondência na fala de crianças com implante coclear na nomeação de figuras e na leitura [Using the equivalence paradigm to increase the correspondence of vocalizations by children with cochlear implant in picture naming and reading]. Psicologia: Reflexão e Crítica, 28, 365-377. doi:10.1590/1678-7153.201528217

Bagaiolo, L. F., \& Micheletto, N. (2004). Fading e exclusão: Aquisição de discriminações condicionais e formação de classes de estímulos equivalentes [Fading and exclusion: Acquisition of conditional discrimination and formation of equivalence relations]. Temas em Psicologia, 12, 168-185.

Battaglini, M. P., Almeida-Verdu, A. C. M., \& Bevilacqua, M. C. (2013). Aprendizagem via exclusão e formação de classes de equivalência em crianças com deficiência auditiva e implante coclear [Learning by exclusion and class formation on children with impaired hearing and cochlear implant]. Acta Comportamentalia, 21, 20-35.

Bevilacqua, M. C. (1998). Implante coclear multicanal: Uma alternativa na habilitação de crianças surdas [Multichannel cochlear implant: An alternative in the ability training of deaf children] (Emeritus Professorship Habilitation Thesis, University of São Paulo, Bauru Faculty of Dentistry, SP, Brazil).

Clark, G. M. (1996). Electrical stimulation of the auditory nerve: The coding of frequency, the perception of pitch and the development of cochlear implant speech-processing strategies for profoundly deaf people. Clinical and Experimental Pharmacology and Physiology, 23, 766-776.

Da Silva, W. R., de Souza, D. G., de Rose, J. C., Lopes, J., Jr., Bevilacqua, M. C., \& McIlvane, W. J. (2006). Relational learning in deaf children with cochlear implants. Experimental Analysis of Human Behavior Bulletin, 24, 1-8.

Delgado, E. M. C., \& Bevilacqua, M. C. (1999). Lista de palavras como procedimento de avaliação da percepção dos sons da fala para crianças deficientes auditivas [List of words as procedure for assessment of perception of speach sounds for hearing impaired children]. Pró-Fono, 11, 5964.

Dixon, L. S. (1977). The nature of control by spoken words over visual stimulus selection. Journal of the Experimental Analysis of Behavior, 27, 433442. doi:10.1901/jeab.1977.27-433

Golfeto, R. M., \& de Souza, D. G. (2015). Sentence production after listener and echoic training by prelingual deaf children with cochlear implants. Journal of Applied Behavior Analysis, 48, 363-375. doi:10.1002/jaba.197 
Greer, R. D., \& Ross, D. E. (2008). Verbal behavior analysis: Inducing and expanding new verbal capabilities in children with language delays. Boston, MA: Pearson Education.

Horne, P. J., \& Lowe, C. F. (1996). On the origins of naming and other symbolic behavior. Journal of the Experimental Analysis of Behavior, 65, $185-$ 241.

Kazdin, A. E. (1982). Single-case research designs. Methods for clinical and applied settings. New York: Oxford University Press.

McIlvane, W. J., Munson, L. C., \& Stoddard, L. T. (1988). Some observations on control by spoken words in children's conditional discrimination and matching by exclusion. Journal of Experimental Child Psychology, 45, 472-495.

McIlvane, W. J., \& Stoddard, L. T. (1981). Acquisition of matching-to-sample performances in severe retardation: Learning by exclusion. Journal of Mental Deficiency Research, 25, 33-48.

Neves, A. J. D. (2014). Compreensão e produção oral de sentenças em crianças com deficiência auditiva pré-lingual usuárias de implante coclear [Compreension and oral production of sentences in children with prelingual hearing disabilities who use pre-lingual cochlear implants] (Master's dissertation, São Paulo "Júlio de Mesquita Filho" State University, Faculty of Sciences, São Paulo, SP, Brazil). Retrieved from http:// hdl.handle.net/11449/132489.

Neves, A. J. D., Verdu, A. C. M. A., MortariMoret, A. L., \& Silva, L. T. D. N. (2015). As implicações do implante coclear para desenvolvimento das habilidades de linguagem: Uma revisão da literatura [The implications of cochlear implant for the development of language skills: A review]. Revista CEFAC, 17, 1643-1656. doi:10.1590/1982-021620151755315
Skinner, B. F. (1957). Verbal behavior. Englewood Cliffs, NJ: Prentice Hall.

Souza, G. N., Jr. (2010). Projeto de software para aprendizagem utilizando discriminação simples simultânea [Software project for learning using simultaneous simple discrimination]. Final Graduation Paper, Bachelor's Course on Information Systems, Federal University of Pará, Faculty of Computing, Institute of Exact and Natural Sciences, Belém, PA, Brazil.

Souza, F. C. de, Almeida-Verdu, A. C. M., \& Bevilacqua, M. C. (2013). Ecoico e nomeação de figuras em crianças com deficiência auditiva pré-lingual com implante coclear [Echoic and picture naming in prelingual impaired hearing children with cochlear implant]. Acta comportamentalia, 21, 325-339.

Wei, C., Cao, K., Jin, X., Chen, X., \& Zeng, F. G. (2007). Psychophysical performance and Mandarin tone recognition in noise by cochlear implant users. Ear and Hearing, 28(Suppl. 2), 62S65S. doi:10.1097/AUD.0b013e318031512c 